\title{
BYZANTINE HEALING AMULETS FROM SOUTHWESTERN CRIMEA ${ }^{1}$
}

\author{
Elzara A. Khairedinova \\ Institute of Archaeology of Crimea of the Russian Academy of Sciences, Simferopol, Russian Federation
}

\begin{abstract}
Introduction. The article presents two unique items from the Southwestern Crimea - a bronze finger ring with an image of a lion-headed serpent Chnoubis, originating from a female burial of the first quarter of the $7^{\text {th }}$ century of the Gothic-Alanian burial ground near the village of Luchistoye, and a bronze medallion, which was found in the area of the village of Goncharnoye, with magic signs, formulas and an image of Chnoubis, which is tied to an altar, fighting a snake. Methods. According to some similar findings from the territory of the Eastern Roman Empire, the ring and the medallion are attributed to the group of Byzantine medical amulets. The amulets of the Early Byzantine time demonstrate continuity with pre-Christian magical practices, therefore, late ancient magical gems and texts were involved to decipher the plots and inscriptions engraved on those amulets. Analysis. The finger ring was intended to improve digestion and to treat diseases of a digestive tract. The woman who owned the item was wearing it in a chest necklace, at the level of her stomach - just as it was recommended in medical treatises to wear amulets for abdominal pain. The medallion was a complex amulet intended for women. Chnoubis in the scene of fighting the snake and the spell ПINO are depicted on both sides of the medallion. In one case, Chnoubis is a guardian of a stomach and a fighter against diseases of the digestive tract, whose actions are enhanced by the three times repeated spell ПINO, which contributes to better digestion. In the second case, Chnoubis is a defender of women's health, and the disappearing word ПINO should help stop pathological uterine bleeding. The action of the amulet is enhanced by a formula against demons that cause disease, and its healing properties are confirmed by the inscription YГІА (health). Such an amulet should be worn suspended from the neck by a long cord, or fastened to the belt. Results. Both items belong to the group of medical magic amulets. They were brought from the Eastern Mediterranean provinces of the Empire, where in the $6^{\text {th }}-7^{\text {th }}$ centuries there were magic amulets similar in form and repertoire of protective means. The appearance of such items among the Gothic-Alanian population of the Southwestern Crimea is not surprising. The influence of the Byzantine civilization on all aspects of the life of the local population in the Early Middle Ages can be traced both from written sources and from numerous archaeological findings.
\end{abstract}

Key words: Byzantium, Southwestern Crimea, finger rings, amulets, Chnoubis.

Citation. Khairedinova E.A. Byzantine Healing Amulets from Southwestern Crimea. Vestnik Volgogradskogo gosudarstvennogo universiteta. Seriya 4. Istoriya. Regionovedenie. Mezhdunarodnye otnosheniya [Science Journal of Volgograd State University. History. Area Studies. International Relations], 2020, vol. 25, no. 6, pp. 82-99. (in Russian). DOI: https://doi.org/10.15688/jvolsu4.2020.6.6

\section{ВИЗАНТИЙСКИЕ ЦЕЛИТЕЛЬНЫЕ АМУЛЕТЫ ИЗ ЮГО-ЗАПАДНОГО КРЫМА ${ }^{1}$}

Аннотация. В статье представлены два уникальных предмета из Юго-Западного Крыма - бронзовый перстень с изображением львиноголового змея Хнубиса, происходящий из женского погребения первой четверти VII в. гото-аланского могильника у с. Лучистое, и бронзовый медальон, найденный в районе с. Гончарное, с магическими знаками, формулами и изображением привязанного к алтарю, борющегося со змеей Хнубиса. Оба изделия относятся к группе медицинских магических амулетов, пользовавшихся широкой популярностью у населения Восточной Римской империи в эпоху раннего средневековья. Перстень 
предназначался для улучшения пищеварения и для лечения болезней пищеварительного тракта. Женщина, которой принадлежал предмет, носила его в нагрудном ожерелье, на уровне желудка - именно так, как рекомендовалось в медицинских трактатах носить амулеты против болей в животе. Медальон был комплексным амулетом, предназначавшимся для женщин. Хнубис в сцене борьбы со змеей и заклинание ПINO изображены на обеих сторонах медальона. В одном случае Хнубис - хранитель желудка и борец с болезнями пищеварительного тракта, чьи действия усилены трижды повторенным заклинанием ПINO, способствующим лучшему перевариванию. Во втором случае Хнубис - защитник женского здоровья, а исчезающее слово ПINO должно способствовать остановке патологических маточных кровотечений. Действие амулета усилено формулой против демонов, вызывающих болезни, а его целительные свойства подтверждаются надписью ҮГІА (здоровье). Носить такой амулет следовало подвешенным к шее на длинном шнурке, либо укрепленным к поясу. Оба предмета были привезены из восточно-средиземноморских провинций империи, где в VI-VII вв. бытовали аналогичные по форме и репертуару защитных средств магические амулеты. Появление таких изделий у гото-аланского населения Юго-Западного Крыма неудивительно. Влияние византийской цивилизации на все стороны жизни местного населения в эпоху раннего Средневековья прослежено и по письменным источникам, и по многочисленным археологическим находкам.

Ключевые слова: Византия, Юго-Западный Крым, перстни, амулеты, Хнубис.

Цитирование. Хайрединова Э. А. Византийские целительные амулеты из Юго-Западного Крыма // Вестник Волгоградского государственного университета. Серия 4, История. Регионоведение. Международные отношения. - 2020. - Т. 25, № 6. - C. 82-99. - DOI: https://doi.org/10.15688/jvolsu4.2020.6.6

Введение. Амулеты являются важным источником для изучения верований и представлений об окружающем мире средневекового населения Юго-Западного Крыма. Различные предметы, украшения и детали одежды, которым приписывали чудодейственную силу от физических недугов, гибельных воздействий и нападений видимых и невидимых врагов, позволяют «заглянуть» в повседневную жизнь древнего человека. Особый интерес представляют амулеты с изображениями и надписями, по которым можно определить их назначение. К такому роду амулетов принадлежат публикуемые предметы - бронзовый медальон, найденный в районе с. Гончарное $^{2}$ (рис. 1,1$)$, и бронзовый перстень, происходящий из женского погребения первой четверти VII в. гото-аланского могильника у с. Лучистое (рис. 2, 3) [10, с. 69-89]. В предлагаемой работе обосновывается атрибуция предметов, выявляется круг аналогий, интерпретируется значение изображений и их защитные свойства, а также рассматриваются особенности ношения амулетов.

Методы. В исследовании применяются методы исторической науки: описание, пояснение, анализ, синтез, сопоставление данных различных источников, системный подход к источникам. Для атрибуции амулетов выявляется круг аналогий, анализируются находки с территории Восточной Римской империи. Амулеты ранневизантийского време- ни демонстрируют преемственность с дохристианскими магическими практиками [39, p. 43], поэтому для расшифровки выгравированных на них сюжетов и надписей необходимо привлекать позднеантичные магические геммы и тексты. В Юго-Западном Крыму один из публикуемых амулетов найден в погребении in situ, в составе закрытого комплекса вместе с инвентарем, имеющим узкую датировку, что позволяет уточнить время бытования этого типа изделий в регионе и определить способ его ношения.

Анализ. Бронзовый пластинчатый круглый медальон, найденный в районе с. Гончарное, отлит с прямоугольной петлей с круглым отверстием для подвешивания и с двух сторон покрыт гравированными изображениями и греческими надписями (рис. 1,1$)$. Его размеры: диаметр 3,5 см; высота 4,0 см. Медальон относится к группе византийских металлических магических амулетов, бытовавших в VI в. в Сиро-Палестинском регионе (рис. 3, 6-10; 4, 1-3). Различаясь формой, репертуаром изображений и надписей, эти изделия, тем не менее, близки по стилю и технике изготовления и, возможно, являются продукцией одной мастерской, функционировавшей, по мнению Дж. Спайера, в Галилее в начале VI в. [39, p. 44].

На обеих сторонах найденного в Крыму медальона в небрежной манере выгравирована фигура привязанного к алтарю змееподоб- 
ного существа и расположенная напротив извивающаяся змея в атакующей позе с открытой пастью. Несмотря на схематичность изображения, в змееподобном существе легко распознать львиноголового змея Хнубиса, хорошо известного по так называемым греко-египетским или греко-сирийским магическим геммам (рис. 2, 4, 5; 3, 4; 5, 1-4), появление и распространение которых связывают с деятельностью гностических сект поздней античности [16, p. 54-60]. Персонаж на медальоне обладает всеми характерными для иконографии Хнубиса чертами: обращенной влево большой львиной головой с семью или двенадцатью лучами на месте гривы, длинным змеиным телом и хвостом, закрученным в одно или несколько колец (рис. $1,1 \partial$ ). На атрибуцию львиноголового змея указывает и выгравированный над его головой знак в виде трех C, перечеркнутых прямой линией, называемый «знаком Хнубиса» (рис. 1, 1в). Этот знак происходит от египетских изображений астрологического декана Кенмет, от которых, как считается, была заимствована и иконография самого Хнубиса [30, p. 64]. Изначально знак представлял собой вертикального змея, держащего горизонтально трех других змей менышего размера [18, p. 294]. Позже извивающиеся змеи трансформировались в перечеркнутые линией символы, близкие по написанию буквам ZZZ, SSS или CСС (рис. 3, 3, 4; 5, 1, 2, 4a).

Хнубис - это астрологический декан созвездия Льва, отвечавший за работу внутренних органов пищеварения и воспроизводства, получивший дополнительный статус солярного божества во время расцвета гностических раннехристианских ересей [18, р. 298]. О «прикладных» функциях Хнубиса сообщается в лапидариях - специальных сборниках, содержащих описания свойств различных камней и минералов и рецепты приготовления из них амулетов. В лапидарии Псевдо-Сократа и Псевдо-Диониса говорится о лечебном действии Хнубиса на желудок: «Выгравируй сnирального змея с головой льва и лучами. Носи этот камень, полностью предотвращающзий боль в желудке и позволяющий хорошо переваривать любую пищу» [18, р. 309, № 4; 27, p. 450].

«Терапевтические» свойства Хнубиса были известны и врачам, использовавшим рецепты по приготовлению «действенных филактериев» против недомоганий в области живота из астрологических трактатов и лапидариев. Так, Гален - знаменитый римский врач греческого происхождения, живший во II в., писал: «...зеленая яшма, носимая как амулет, полезна для пищевода и устья желудка. Некоторые вставляют гемму в перстень и гравируют на ней змею с лучами...» [18, p. 309, № 5]. Перстни, украшенные каменной вставкой с таким изображением, бытовали во многих провинциях Римской империи (рис. 2, 5) [32, p. 149-150, fig. 126]. То, что резные камни с изображением Хнубиса предназначались для улучшения пищеварения или для лечения болезней пищеварительного тракта, подтверждается и выгравированными на самих геммах обращениями: «Храни в здравии желудок Прокла!» (рис. 5, 3); «Хнумис, избавь Юлиана, рожденного Нонной, от всякого напряжения, всякого несварения, всякой боли в желудке», «Хнубис, переваривай, переваривай!»; «Переваривай, переваривай!»; «Для желудка Сосибия»; «Хнубис, успокой боль желудка...» [17, p. 292, № 2189; 18, p. 310, № 8]. На некоторых геммах змеиное тело Хнубиса стилизовано под изображение кишечника. На одной из инталий, найденной в Сирии, выгравирована надпись «для желудка или Хнубис». По предположению Р. Мутерда, резчик по камню механически скопировал рецепт, в котором предлагалось выбрать одну из двух надписей [31, p. 74]. Видимо, понятия «Хнубис» и «здоровье желудка» в представлении древних были синонимами.

Аналогичное лечебное воздействие на желудок имел и знак Хнубиса, изображенный один, без фигуры декана. Известно несколько магических гемм с различными персонажами, на обороте которых присутствует только знак Хнубиса и надпись: «Переваривай!» (рис. 3, 3). На инталии из Керчи, хранящейся в Эрмитаже, рядом с этим знаком прорезана надпись $\Sigma$ ТОМАХОY - «для желудка» [7, c. 98, кат. № 3]. Марцелл Эмпирик, медик и фармаколог времен императора Феодосия I, практикующий врач, о чем свидетельствует его прозвище «Эмпирик», считал, что данный знак имеет магическую силу исцелять сам по себе. В своем сочинении De medicamentis, в 
разделе, посвященном лечению плеврита и болей в боках, Марцелл пишет: «Если знаки, указанные ниже [SSS], будут вырезаны на фригийской прозрачной ямме, а получившаяся гемма одета на цепочку и повешена на шею страждущеег, результат будет чудодейственным» [22, р. 51-52; 28, р. 244, Cap. XXIV, 7].

В более позднее время, с утверждением христианства, традиция ношения амулетов не исчезла. О суеверии византийцев хорошо известно по письменным источникам и многочисленным находкам амулетов. Магия процветала не только у простолюдинов, но и в среде риторов и философов [8, с. 87]. Носить амулеты рекомендовали даже врачи. Так, Александр из Тралл (525-605 гг. н.э.), знаменитый медик, которого Агафий Миринейский назвал «опытнейшим во врачебном искусстве» [1, с. 143], советовал для страдающих от колик в животе использовать специальный амулет: «на медийском камне вырежи Геракла, душащего льва, вставь этот камень в золотое кольцьо и дай его носить» [16, р. 62]. Эта рекомендация не была «теоретической». Геммы с таким сюжетом, часто сопровождающимся еще и знаком ККК, достаточно широко представлены не только в позднеантичной глиптике, но известны и в раннесредневековое время [16, p. 62-64, pl. V, 108-110; 22, р. 52, pl. 5-7; 35, p. 86-87].

В созданном около 415 г. Гефестионом Фиванским трактате по классической астрологии «Апотелесматика» можно прочитать о том, что Хнубис - «третий декан созвездия Рак» и «защита для желудка» [16, р. 55; 18, p. 309, № 3]. Сочинение Гефестиона пользовалось большой популярностью у византийцев на протяжении многих веков [43, p. 914]. Достаточно долго существовало представление о защитных функциях астрологических деканов. Об этом свидетельствует тот факт, что даже в XI в. Михаил Пселл указывал на практику гравировки на перстнях или кольцах «деканов в разных формах» для получения мощного филактерия [18, p. 296].

В средние века изображение Хнубиса встречается на бронзовых браслетах-амулетах вместе с христианскими сюжетами и надписями. Речь идет о происходящих из Египта браслетах VI-VII вв., сделанных из узкой пла- стины с медальонами, внутри которых выгравированы сцены христологического цикла (рис. 5, 5, 7) [29, p. 247-248, fig. 1; 44, p. 76-77, fig. 8, 9; 45, p. 35, 37, fig. 9b, 10d]. Свободное пространство между медальонами заполнено первыми строками Псалма 90. В одном из медальонов видно уже знакомое по геммам изображение Хнубиса: змеевидное тело выгравировано схематично, но зато хорошо проработана львиная голова на фоне солнечного диска с семью лучами (рис. 5, 5a, 7a). Рядом присутствуют и характерные для магических инталий знаки, из которых наиболее отчетливо читается пентальфа. Зная свойства Хнубиса, можно говорить о том, что в «обязанности» браслета входило и обеспечение здоровья органам пищеварения.

В Лувре хранится найденная в Египте медная пластина VIII-IX вв., сделанная в виде прямоугольника с заостренной верхней частью, с круглым отверстием для подвешивания (рис. 5, б). На обеих сторонах пластины выгравированы человеческие фигуры, животные, различные магические знаки, греческие и арабские надписи [15, p. 285, № AF11704]. К.А. Фараон считает этот необычный предмет своеобразным сборником образцов, висевшим на стене мастерской перед ремесленником, изготавливавшим на заказ различные амулеты [23, p. $187-$ 220]. На одной из сторон видны легко узнаваемые по короне из лучей, по спирально закрученному телу изображения Хнубиса на пьедестале, а в прочерченных рядом надписях читается и его имя (рис. 5, 6a).

В качестве примера долгого существования и широкого распространения зародившихся в Египте еще в античный период представлений о защитных и терапевтических свойствах декана и солярного божества Хнубиса следует назвать и бронзовый перстень, найденный в Юго-Западном Крыму, в одном из женских погребений первой четверти VII в. из могильника у с. Лучистое (рис. 2, 3). Перстень диаметром 2,4 см отлит из бронзы с узкой, сегментовидной в сечении шинкой и овальным, расположенным поперечно плоским щитком размером 1,0 × 1,6 см. На щитке вырезано расположенное между двумя полумесяцами изображение змея с львиной головой в нимбе вправо. Тело змея покрыто поперечными насечками, а хвост закручен. Существо, 


\section{ВИЗАНТИЙСКАЯ ТАВРИКА}

изображенное на щитке перстня, имеет несомненное иконографическое сходство с Хнубисом. Тождество с изображениями на инталиях особенно заметно по оттиску (рис. 2, 3б), сделанному с перстня.

Женщина, похороненная в Лучистом, знала о «магической» и «лечебной» силе изображенного на нем существа и использовала перстень именно как амулет, а не в качестве украшения с диковинным декором. Основанием для такого предположения является тот факт, что перстень был найден не на фалангах пальцев рук, на месте традиционного расположения колец и перстней в погребениях, a лежал в области груди, среди бус и подвесок, нанизывавшихся на нить, соединяющую фибулы. В VI-VII вв. жительницы Юго-Западного Крыма часто украшали фибулы, наплечные парные застежки, низкой крупных бус, чередующихся с различными металлическими подвесками. Такие низки были скоплением амулетов. В них носили отличающиеся большими размерами бусы из слегка подправленной янтарной гальки, из меловой породы и горного хрусталя, из полихромного стекла с пятнистым или «глазчатым» орнаментом, а также бронзовые колокольчики, звон которых, по представлению древних, отвращал зло [2, с. 258].

Перстень, висевший в нагрудном ожерелье, находился в области желудка носившей его женщины (рис. 2, 2). Именно так рекомендовал носить амулеты против болей в желудке врач Гален: «Я сделал небольшое ожерелье из некрупных камней яшмы и повесил его как нашейный амулет, придав ему такую длину, что камни достигали начала желудка» [16, р. 54; 18, p. 309, № 5]. Спустя четыре века, другой врач - Аэций из Амиды слово в слово повторил рецепт Галена [18, p. 309-310, № 7].

На публикуемом медальоне из Крыма Хнубис представлен в необычной для этого персонажа сцене: привязанным к алтарю и противостоящим атакующей его змее с открытой пастью. Изображенное действие подписано трижды повторяющимся греческим словом ПINO. Сюжет отсылает к ранневизантийским пластинчатым овальным амулетам с петелькой для подвешивания, найденным в Сиро-Палестинском регионе (рис. 3, 6-
10). На лицевой стороне этих подвесок выгравированы святой всадник, пронзающий копьем распростертого под конем женского демона, и надпись «Единственныц бог, побеждающий зло», придающие амулету характер универсального защитного средства от всякого зла [9, с. $155-160,197$, рис. $4 ; 35$, р. 80 83, № 7-12; 41, CBd-811, CBd-812]. На обратной стороне изображены привязанная к колонне или алтарю птица - ибис (или цапля?), нападающая на змею, и надпись ПIN $\Omega$, которая переводится как «я пью» $[16$, р. 212-213; 36, p. 3]. Сюжет византийских амулетов восходит к магическим геммам позднеримского времени с привязанным к алтарю ибисом, которые защищали от болезней пищеварительного тракта, о чем свидетельствует и часто присутствующее на них трехкратное повеление больному желудку «Переваривай!» (рис. $3,1,2,4)[16$, p. $51-53 ; 18$, p. 300; 36, p. 2-3, fig. 2]. Птицу, изображенную на металлических подвеска-амулетах, также интерпретируют как страуса, хорошо известного своим ненасытным аппетитом и сильной пищеварительной системой. В этом случае надпись ПIN $\Omega$ переводится как «я голоден»

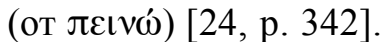

Считается, что магия птицы (ибиса, цапли или страуса) заключалась в ее невероятной пищеварительной силе, которую амулеты с подобной иконографией должны были передать носителю. Кроме того, в Египте большие птицы с длинным клювом, особенно ибис, считались наделенными защитными свойствами, поскольку они истребляли змей, скорпионов, саранчу - всех тех существ, которые в повседневной жизни угрожали человеку [36, p. 1]. В представлении египтян ибис никогда не пил отравленную или грязную воду, то есть воду, которая может вызвать болезнь или даже смерть [24, p. 342]. Не исключено, что амулеты-подвески с птицей и надписью ПIN $\Omega$, служившие, прежде всего, защитой для слабого желудка, также могли быть полезными при отравлениях и против ядовитых рептилий или всеобщего зла, обозначенного змеей.

В свете сказанного замена привязанной к алтарю птицы Хнубисом (рис. 1, 1), отвечавшим за здоровье пищеварительной системы человека, выглядит закономерным. Напомним, что на реверсе некоторых «желудоч- 
ных» амулетов римского времени с ибисом и алтарем часто размещали еще и Хнубиса или его знак, изображение которых должно было увеличить лечебное действие филактерия (рис. 3, 3).

Целительные и дижестивные свойства Хнубиса на публикуемом медальоне усилены трижды повторенным греческим словом ПINO, которое в разных написаниях (ПINO или ПIN $\Omega$ ) встречается отдельно или в составе заклинаний, выгравированных на византийских амулетах VI в. с изображением волка и крокодила, предназначавшихся для улучшения пищеварения (рис. 4, 1-3) [39, р. 6265, fig. 12-14]. Текст таких заклинаний сводился к следующему: «Голодного волка кормили. Я пью воду, я хочу пить, я ем хлеб»; «Я голодный волк, пью в канаве, высушенной голодом»; «Голодного волка кормили (я пью) в канаве (или могиле), высушенной голодом» [39, р. 61-64]. Смысл несколько абсурдного по содержанию текста становится понятным при прочтении его латинской версии в сочинении начала V в. De medicamentis Марцелла Эмпирика. В разделе, где собраны различные средства против болезней желудка, Марцелл рекомендует для хорошего переваривания пищи на ночь, лежа в постели произносить трижды: «Волк шел по тропинке. Сырую пищу он пожирал, жидкости он выпил〉 (Cum te in lecto posueris, ventrem tuum perfricans dices ter: Lupus ibat per viam, per semitam, cruda vorabat, liquida bibebat) [28, p. 204, Сар. XX, 78]. На одном из амулетов внутри написанного по кругу такого заклинания помещено и изображение птицы, атакующей змею (рис. 4, 2), в миниатюрной форме повторяющее сцену на упомянутых выше подвесках со святым всадником (рис. 3, 6-10), что еще раз подтверждает схожее назначение амулетов с разными сюжетами, подписанными словом ПIN $\Omega$. Сокращенный вариант заклинания, усеченный до одного лишь слова ПINO и проиллюстрированный волком и крокодилом, встречается на ранневизантийских перстнях (рис. 4, 3a), которые, как нами было показано выше, могли использоваться не только как украшение, но и в качестве амулетов. Интересно, что заклинания против болезней живота, магическое действие которых основано на поглощении жидкости, известны в гре- ческом фольклоре вплоть до нового времени. В качестве примера можно привести врачевательную молитву, бытовавшую в XVIIIXIX вв. у греков Приазовья, потомков христианского средневекового населения Юго-Западного Крыма: «...Запрети болезни живота раба Божьего. Подобно Христу, орел ушел в высь небесную; нагнулся испить, ни меда не выпил, ни молока не выпил, выпил болезнь живота...» [5, с. 73-74, 144, № 14, примеч. 44].

Трижды прописанное заклинание - прием, характерный для магических амулетов. На обратной стороне гемм римского времени, защищающих от болезней пищеварительного тракта, с привязанным к алтарю ибисом гравировали трехкратное повеление «Переваривай!» (рис. $3,1,2$ ). На византийских амулетах часто встречается трисагион (АГІОС АГІОС АГІОС) - стандартная формула у иудеев и христиан против злого духа [20, S. 316-317, № 586; 34, p. 39; 38, p. 84, 86, № 481; 45 , p. 40-41, № 5, 22, fig. 8, 5b]. Такие заклинания прописывали не только в одну строку, но и расположив слова в разном направлении относительно друг друга (рис. 4, 7, 9). На одной из сторон публикуемого медальона слово ПINO дважды написано горизонтально, одно под другим, третье слово размещено вертикально (рис. 1, Б). Также выгравирован трисагион на ранневизантийских медальонах «Печатях Соломона» (рис. 4, 7, 9).

Наряду с лечебным воздействием на пищеварительную систему, публикуемый медальон мог быть наделен и другими функциями. Сюжеты с Хнубисом и привязанным к алтарю ибисом, представленные на византийских металлических подвесках, восходят к сценам на позднеантичных геммах - «утробных» амулетах, получивших свое название по стилизованному изображению утробы или женской матки с расположенным под ней ключом, на который «запирался» орган (рис. 1, 2-6). Нетрудно заметить, что и по форме, и по размерам публикуемый бронзовый медальон копирует некоторые каменные «утробные» амулеты IV-V вв. (рис. 1, 3), которые делали из черного гематита, темно-зеленого стеатита или серпентина и в отличие от других гемм - с петелькой для подвешивания и ношения в качестве нагрудного медальона. Ря- 
дом с утробой на геммах помещались фигуры божеств-защитников (Анубиса, Осириса, Исиды, Нефтиды, Хнубиса), а на обратной стороне - ибис, который должен утолять или же сдерживать боль, как о том говорит надпись, приказывающая «Переваривай!», часто в сопровождении знака Хнубиса. На геммах встречается имя Орориуфа, защитника матки, сущности, контролирующей роды. «Утробные» геммы с маткой и ключом считаются комплексными женскими амулетами, использовавшимися в качестве защитного средства для беременных и рожениц, как обереги против внутренних кровотечений, в том числе болезненных нарушений менструальных циклов, и как филактерии от желудочных и кишечных расстройств [18, p. 300; 30, p. 64]. По мнению А. Мастрочинкве, магическая сила Хнубиса на геммах этого типа основана на той идее, что декан созвездия льва, управляющий водами нильского разлива, способен также регулировать женские кровотечения, стимулировать течение грудного молока и предотвращать внутренние кровотечения, язвы и ненормальные пищеварительные соки в желудке или кишечнике [30, p. 64]. В лапидарии Псевдо-Сократа и Псевдо-Дионисия именно для беременных женщин и кормящих матерей рекомендовалось на черном ониксе гравировать Хнубиса [18, р. 309, № 4-36].

На одной из сторон публикуемого медальона, вдоль верхнего и правого края выгравировано загадочное сочетание букв $-X E$ [Q?] IOIPRH (рис. 1, Б). Буква «R» - это открытая форма беты, один из вариантов ее написания, хорошо известный по магическим геммам, египетским браслетам, «Печатям Соломона» и металлическим амулетам с Истерой $[29$, p. $257 ; 37$, p. $32 ; 40$, p. 292 , Cat. N 241]. На медальонах - «Печатях Coломона» открытая бета прочерчена в наборе букв RPSSS или RSSS (рис. 4, 6, 8, 9), значение которых утеряно. Судя по контексту, они входили в набор защитных средств, наделявших медальоны магической силой $[9$, с. $168-$ 169]. Буквенные сочетания типа -IPBH- или -EPBE- встречаются в составе длинных, не поддающихся переводу формулах $(\log o s)$ на позднеантичных «утробных» амулетах (рис. 1, 2) и в греческих магических папирусах (в виде $\iota \omega \varepsilon \rho \beta \eta \theta-\log o s)$, датирующихся III-XI вв. [26, p. 188, 199]. Такие цепочки слов из одинаковых звуков в различных комбинациях, не поддающиеся расшифровке современным исследователям, вероятно, в древности являлись узнаваемой частью магического кода. По мнению К. Бонера, повторение слогов в середине фразы на манер бормотания показывает, что эта формула лишена смысла, а ее ценность частично заключается в произведении впечатления на непосвященных своим таинственным звучанием [16, p. 57]. Р. Эрнандес обратил внимание на то, что в греческих магических папирусах формула $\iota \omega \varepsilon \rho \beta \eta \theta$ в различных сочетаниях часто встречается в заклинаниях агрессивного, злонамеренного характера [26, p. 188, 199]. На амулетах такие формулы могли использоваться в качестве угрозы для болезни или демона, ее вызывавшего.

В одном из греческих магических папирусов IV в. (Papyri Graecae Magicae IV, 1227-64) записан обряд по изгнанию демона, для успешного завершения которого освобожденному человеку рекомендуется носить филактерий из оловянной пластины со словами, включавшими различные вариации слогов -OPBA-, - $A B P A$-, $-A P B A$ - или с прочерченным знаком в виде одиночной S [42, p. 62]. Обратим внимание на то, что и на «утробных» амулетах, и на публикуемом медальоне с Хнубисом с правой стороны от изображений выгравирована маленькая изогнутая линия в виде буквы S (рис. 1, 12, 3б). На одной стороне медальона знак размещен рядом с Хнубисом (рис. $1, A$ ), а на второй - им завершается магическая формула IOIPBH (рис. 1, Б). Учитывая терапевтический характер медальона, закономерно предположить, что магическая формула и знак должны были способствовать изгнанию демонов, вызывающих болезни.

Присутствие одинаковых магических средств (привязанный к алтарю Хнубис - как вариант привязанного к алтарю ибиса, формула типа -IPBH-, знаки Хнубиса и в виде $\mathrm{S}$ ), подобие формы и размеров позволяет заключить, что в сферу защитных обязанностей публикуемого медальона входили и некоторые функции «утробных» амулетов. Не противоречит такому выводу и заклинание ПINO, которое, помимо действия на органы пищеварительной системы, имело еще одно назначение. Так, названная формула встречается на 
средневековых медальонах со святым всадником Сисинием - победителем многоименной дьяволицы Гиллу, которая вредила женщинам во время родов и истребляла младенцев во чреве матери или вскоре после их рождения [9, с. 171-178; 46, р. 241]. На обратной стороне одного из таких медальонов изображена извивающаяся змея с двумя скорпионами и нападающая на них птица с надписью над головой ПIN $\Omega$ (рис. 4, 4) [41, CBd-1078]. На обороте второго медальона, происходящего из Малой Азии и датирующегося X-XII вв., формула ПIN $\Omega$ размещена рядом со стилизованным изображением Истеры (женской матки) в виде змеи с человеческим лицом и волосами-змеями (рис. 4, 5) [4, с. 329-347; 37 , p. 30, 55, pl. 3a, № 33]. На лицевой стороне медальона по контуру прорезана формула, изгоняющая дьяволицу Авизу / Гиллу, а на обороте - заклинание против Истеры. Появление надписи ПIN $\Omega$ рядом с Истерой, по мнению Дж. Спайера, должно означать «я пью кровь» и рассматриваться в контексте врачевательной магии, как останавливающее кровотечение заклинание [37, р. 46-47].

О том, что связанное с питьем жидкости заклинание могло иметь отношение к женским кровотечениям, свидетельствует серия позднеантичных гемм со стилизованным изображением матки в виде сосуда и магической формулой, регулирующей кровотече-

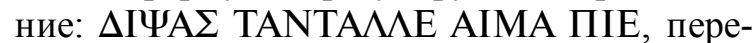
водимой как «Жаждущчий Тантал, пей кровь» (рис. 3, 5) [21, р. 248-259]. Обращение по поводу остановки кровотечения к мифическому персонажу, наказанному муками неутолимой жажды, объясняется тем, что в царстве Аида любая попытка Тантала напиться воды приводила к высыханию водного источника $[16$, p. $88 ; 21$, p. 249]. На геммах формула прописана 18 раз, в 18 строк и имеет вид треугольника. В каждой последующей строке повторяющаяся фраза сокращена на одну, первую букву; в последней строке оставлена только одна, последняя буква заклинания. Такая форма написания волшебной формулы характерна для магических амулетов. Считалось, что заклинание подействует с исчезновением текста, а в данном случае - кровотечение остановится [14, p. 273; 21, p. 249].
А. Барб указал на принадлежность к одной магической традиции гемм с жаждущим Танталом и амулетов против кровотечений, два рецепта которых сохранились в средневековых латинских медицинских справочниках [14, p. 271-273]. Согласно первому рецепту, служившему для остановки кровотечения из носа, требовалось кровью больного написать на трех лавровых листьях заклинание: “Tantale pie, pie Tantale, Tantale pie!” («Taнтал, пей! Пей, Тантал! Тантал, пей!»), в котором использовалось транслитерированное на латынь греческое слово ПІЕ [14, р. 271272]. Второй рецепт предназначался для остановки кровотечений в целом. Для этого рекомендовалось написать заклинание «Подобно тому, как амулет не касается земли, так пей кровь, Тантал! Тантал пей кровь, пей Тантал!» на папирусе, который затем следовало при помощи нити привязать мужчине на шею, а женщине - на живот, в области пупка. Последняя рекомендация, по мнению А. Барба, связана с тем, что мужчины должны были использовать амулет против кровотечений из носа, а женщины - против маточных кровотечений [14, p. 273].

Марцел Эмпирик советовал записать на чистом папирусе, обвязать льняной нитью и прикрепить к тому, у кого течет кровь из любой части тела, следующее заклинание: «sicycuma, cucuma, исuma, сuma, uma, ma, а» [28, p. 110, Сар. Х.34]. А. Фараон предположил, что исчезающее по одной букве слово первоначально было транслитерированным на латынь греческим «ки̃ $\mu \alpha$ (волна или наводнение) и непосредственно относилось к кровотечению. Магия заклинания заключалась в том, что сокращение слова с его последующим исчезновением должно было производить аналогичное действие на кровотечение [21, p. 268-269]. Обратим внимание на особенность написания заклинания ПINO на одной из сторон публикуемого медальона (рис. $1, A$ ). Три слова выгравированы одно под другим, при этом в последующей строке каждое сокращено на одну букву: ПINO ПIN ПІ О. Возможно, мастер, сделавший амулет, не хотел размещать текст поверх изображения и сократил слова. Не исключено, что в данном случае был применен описанный выше магический прием - сокращение на одну букву зак- 
линания в каждой повторяющейся строке, то есть использование исчезающего слова для регулирования потока крови.

Амбивалентность использованных магических средств позволяет говорить о комплексном характере публикуемого медальона. Хнубис в сцене борьбы со змеей и заклинание ПINO изображены на обеих сторонах медальона. В одном случае Хнубис - хранитель желудка и борец с болезнями пищеварительного тракта, чьи действия усилены трижды повторенным заклинанием ПINO, способствующим лучшему перевариванию (рис. $1, Б$ ). Во втором случае Хнубис - защитник женского здоровья, а исчезающее слово ПINO должно способствовать остановке патологических маточных кровотечений (рис. $1, A$ ). Действие амулета усилено формулой против демонов, вызывающих болезни. Терапевтические свойства амулета подтверждаются

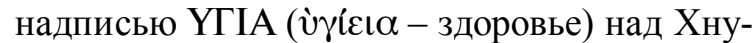
бисом на одной из сторон амулета. Именно в таком написании слово «здоровье» чаще всего встречается на различных ранневизантийских амулетах, перстнях, браслетах, штампах для просфор, а также на атрибутах брачного ритуала $[13$, p. 283, Nr. $262 ; 19$, S. 152-153, Nr. 38; 25, p. 30; 33, p. 266-280].

О том, как носился медальон, можно судить по изображению на раннесредневековой каменной литейной форме, найденной в юго-восточном районе Херсонеса, около крепостной стены $[47$, р. 169, 451, № 50]. Форма предназначалась для изготовления креста, медальона и подвески в виде створки раковины. Медальон, отлитый в форме, служил амулетом (рис. 2, 1), призванным отвращать от носящего беды, как о том свидетельствует вырезанная по контуру надпись +KYPIE

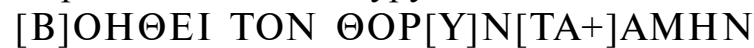
(«Боже, помоги носящему, аминь!») [6, c. 28]. В центре медальона помещено поясное изображение человека в позе оранта, с крестами в руках, к шее которого на длинном шнурке подвешен большой круглый медальон, достигающий живота (рис. 2, 1). Можно предположить и другой вариант ношения медальона - подвешенным к поясу, в области пупка, как это рекомендовалось делать для папирусов с заклинанием против маточных кровотечений [14, p. 273].
Результаты. Найденные в Юго-Западном Крыму амулеты - перстень первой четверти VII в. и медальон VI-VII вв. с изображением Хнубиса - относятся к группе медицинских магических амулетов, пользовавшихся широкой популярностью у населения Восточной Римской империи в эпоху раннего средневековья. Перстень предназначался для улучшения пищеварения и для лечения болезней пищеварительного тракта. Женщина, которой принадлежал предмет, носила его в нагрудном ожерелье, на уровне желудка - именно так, как рекомендовалось в медицинских трактатах носить амулеты против болей в животе. Медальон с магическими знаками, формулой ПINO и изображением привязанного к алтарю Хнубиса, борющегося со змеей, был комплексным амулетом, предназначавшимся для женщин. Он служил защитой для пищеварительной системы и оберегал от патологических маточных кровотечений. Носить такой амулет следовало подвешенным к шее на длинном шнурке, либо укрепленным на поясе.

Оба предмета были, скорее всего, привезены из восточно-средиземноморских провинций империи, где в VI-VII вв. бытовали аналогичные по форме и репертуару защитных средств магические амулеты. Появление таких изделий у гото-аланского населения Юго-Западного Крыма неудивительно. Влияние византийской цивилизации на все стороны жизни местного населения в эпоху раннего Средневековья прослежено и по письменным источникам [3, с. 10-11], и по многочисленным археологическим находкам $[11$, c. $94 ; 12$, c. $33-46]$.

\section{ПРИМЕЧАНИЯ}

${ }^{1}$ Работа выполнена в рамках реализации проекта РНФ № 20-18-00076 «Эволюция городов на Внутренней гряде Крымских гор в Средние века и Новое время».

The study was funded by the Russian Science Foundation according to the research project № 20-18-00076 “The evolution of cities on the Inner ridge of the Crimean mountains in the Middle Ages and modern times".

${ }^{2}$ Медальон хранится в частной коллекции В.В. Булычева. Пользуясь случаем, выражаю глубокую благодарность Валерию Васильевичу за возможность опубликовать уникальную находку. 


\section{ПРИЛОЖЕНИЕ}

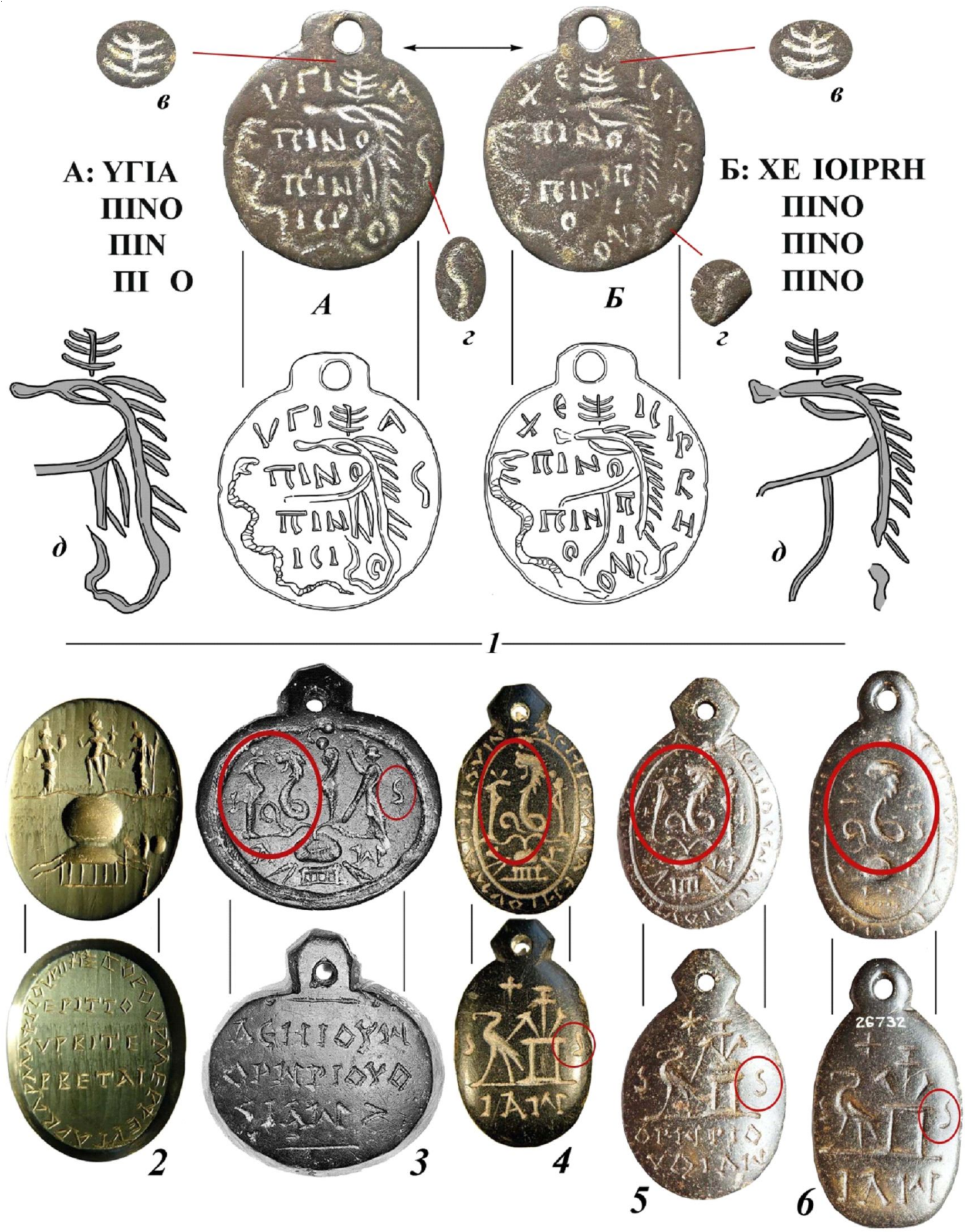

Рис. 1. Раннесредневековый бронзовый медальон из Юго-Западного Крыма (1) и «утробные» каменные амулеты позднеантичного времени (2-6):

1 - частная коллекция (фото В.А. Сидоренко; прорисовка автора); 2, 4 - Париж, Кабинет Медалей; $3,5,6$ - Британский Музей.

2-6- [41, CBd-3423; CBd-136; CBd-3418; CBd-780; CBd-163]

Fig. 1. An early medieval bronze medallion from the South-Western Crimea (I) and "uterine" stone amulets of the late ancient period (2-6):

1 - a private collection (photo by V.A. Sidorenko; sketch by the author); 2, 4- Paris, Cabinet des Médailles; 3, 5,6-The British Museum 


\section{ВИЗАНТИЙСКАЯ ТАВРИКА}

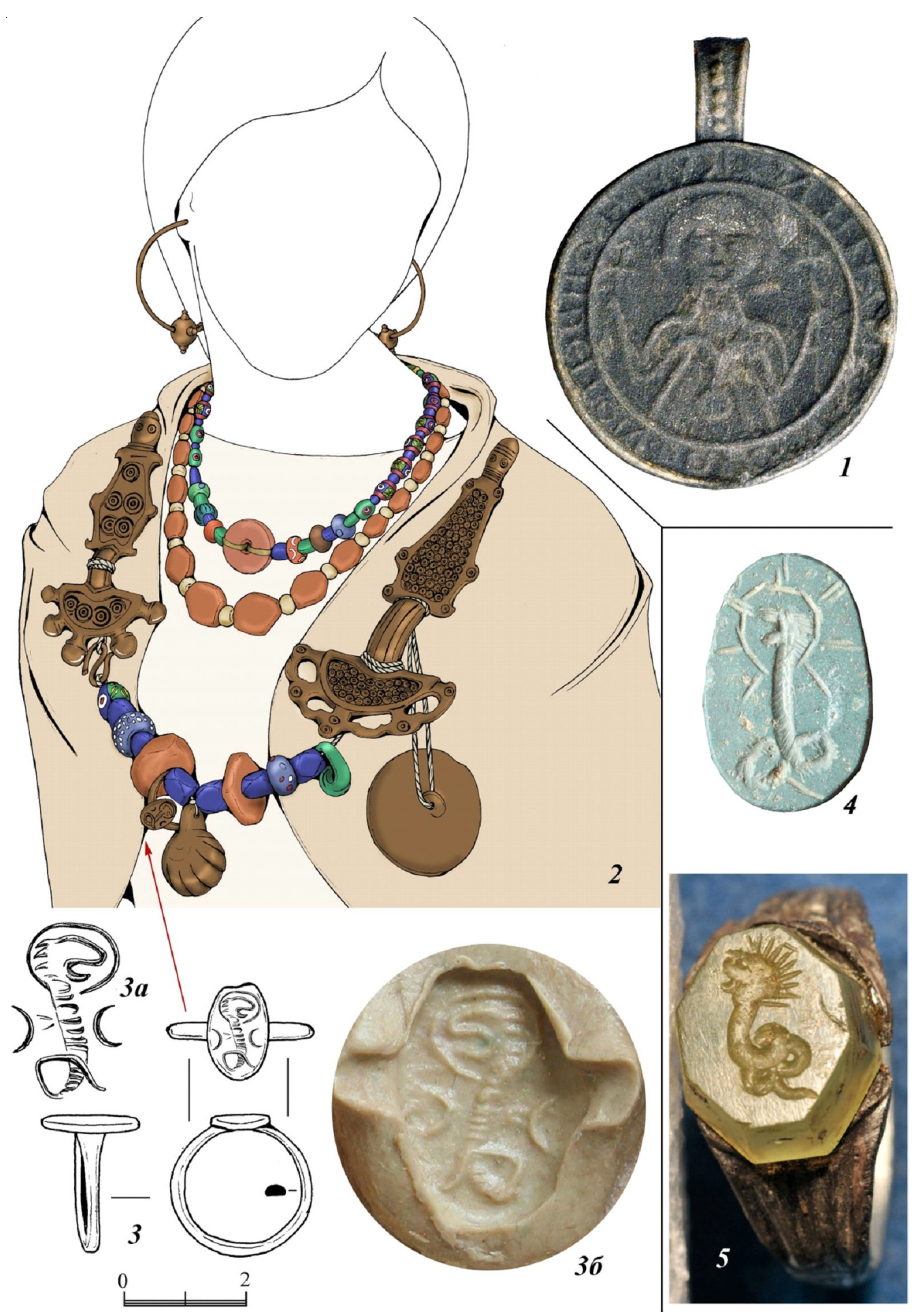

Рис. 2. Перстни и гемма с изображением Хнубиса (3-5), реконструкция гото-аланского женского убора первой четверти VII в. (2) и деталь раннесредневековой каменной литейной формы с медальоном (1):

1 - Херсонес; 2, 3 - могильник у с. Лучистое, склеп 154, погребение 2 ( $a$ - прорисовка;

$\sigma$ - оттиск; фото, реконструкция и рисунок автора); 4 - Британский Музей; 5 - Констанца, Румыния.

1 - [47, p. 169, 451, № 50]; 4 - [41, CBd-703]; 5 - [32, p. 149-150, fig. 126]

Fig. 2. Finger rings and gems with the image of Khnubis (3-5), a reconstruction of the Gothic-Alanian female attire of the first quarter of the 7th century (2) and a part of an early medieval stone casting mould with a medallion ( 1 ):

1 - the Chersonese; 2, 3 - the burial ground near the village of Luchistoye, a crypt 154, a burial 2 ( $a$ - sketch;

$b$ - print; photo, a reconstruction and drawing by the author); 4 - The British Museum; 5 - Constanța, Romania 

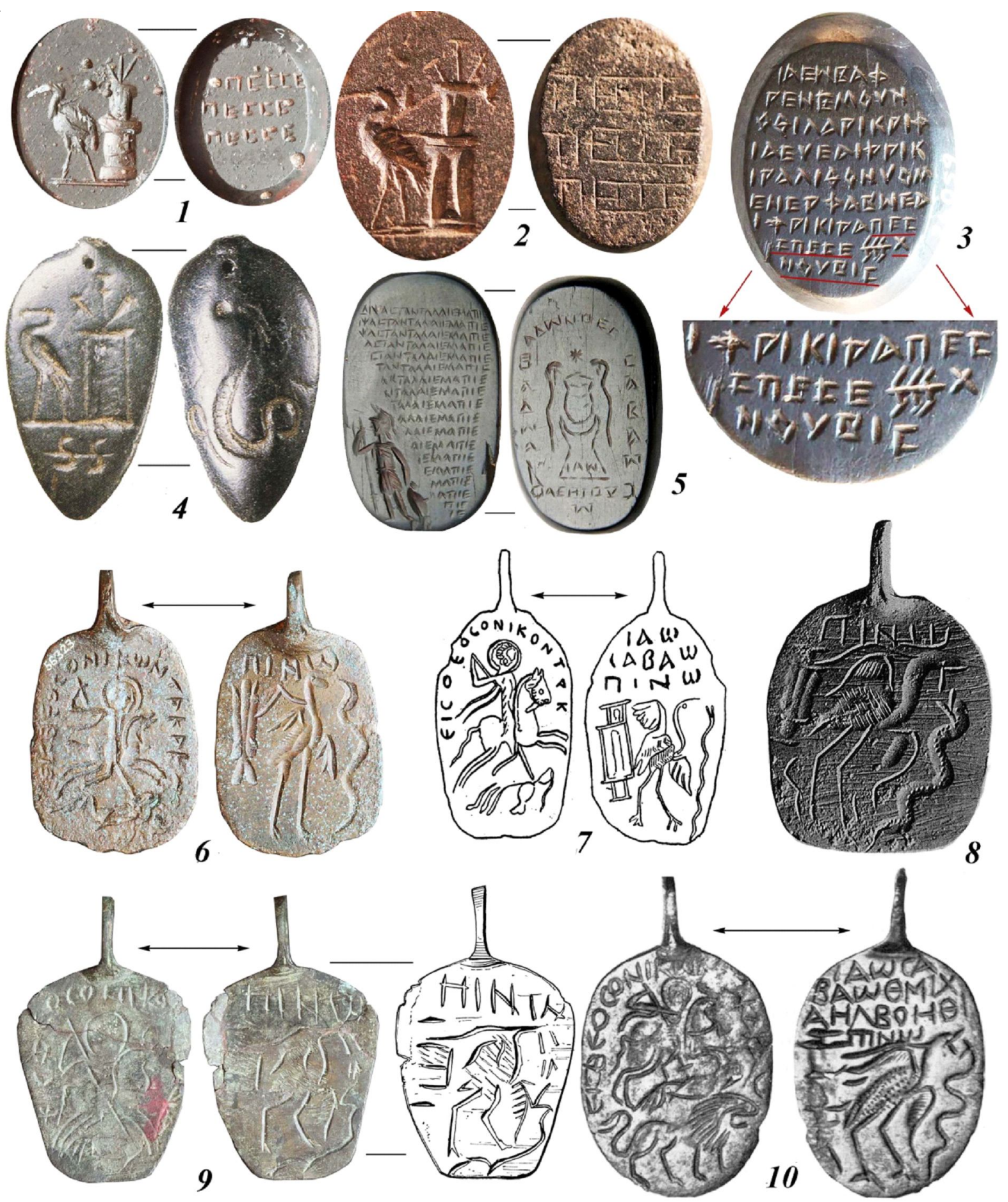

Рис. 3. Позднеантичные геммы (1-5) и раннесредневековые бронзовые амулеты (6-10):

1, 6, 9 - Британский Музей; 2, 3, 8 - Энн-Арбор, Мичиганский университет; 4 - Гамбург, коллекция В. Сколуды; 5 - Париж, Кабинет Медалей; 7 - коллекция Г. Шлюмберже; 10 - Бирмингем, City Museum. 1-6, 8, 9 - [41, CBd-776; CBd-1039; CBd-1441; CBd-1737; CBd-3555; CBd-811; CBd1074; CBd-812]; 7 - [35, p. 81, Nr. 8$] ; 10-[39$, p. 47 , fig. 2]

Fig. 3. Late ancient gems $(1-5)$ and early medieval bronze amulets $(6-10)$ :

1, 6, 9 - The British Museum; 2, 3, 8 - Ann Arbor, University of Michigan; 4- Hamburg, Skoluda Collection; 5 - Paris, Cabinet des Médailles; 7 - the collection of G. Schlumberger; 10 - Birmingham, The City Museum 


\section{ВИЗАНТИЙСКАЯ ТАВРИКА}
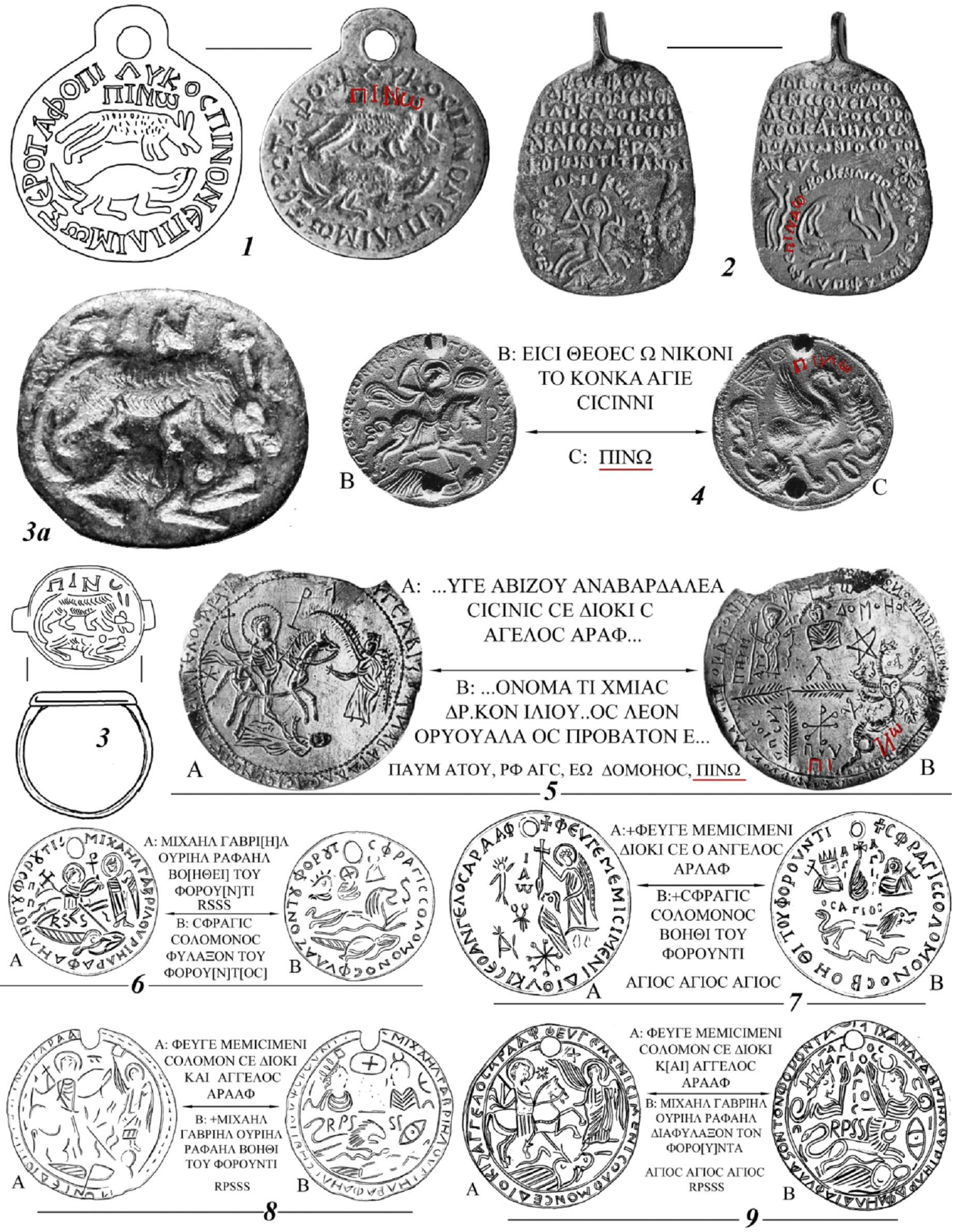

Рис. 4. Византийские амулеты с формулой ПIN $\Omega(1-5)$ и медальоны «Печати Соломона» (6-9):

1-3 - Восточное Средиземноморье, частная коллекция; 4 - коллекция К. Боннера; 5 - Оксфорд, музей Эшмола; 6 - Париж, Кабинет Медалей; 7 - Эрмитаж; 8 - Херсон, Северный район, квартал IX; 9 - Кизик, Малая Азия.

$1-3$ - [39, p. 63-64, fig. 12-14]; 4- [41, CBd1078]; 5 - [37, p. 30, 55, pl. 3a, No. 33]; 6-9- [9, рис. 7, 9; 8, 2-4]

Fig. 4. Byzantine amulets with the formula $\Pi I N \Omega(1-5)$ and medallions "The Seals of Solomon" (6-9): 1-3 - The Eastern Mediterranean, a private collection; 4 - the collection of C. Bonner; 5 - Oxford, The Ashmolean Museum; 6 - Paris, Cabinet des Médailles; 7 - the Hermitage; 8 - Kherson, the Northern region, quarter IX; 9 - Kizik, Asia Minor 

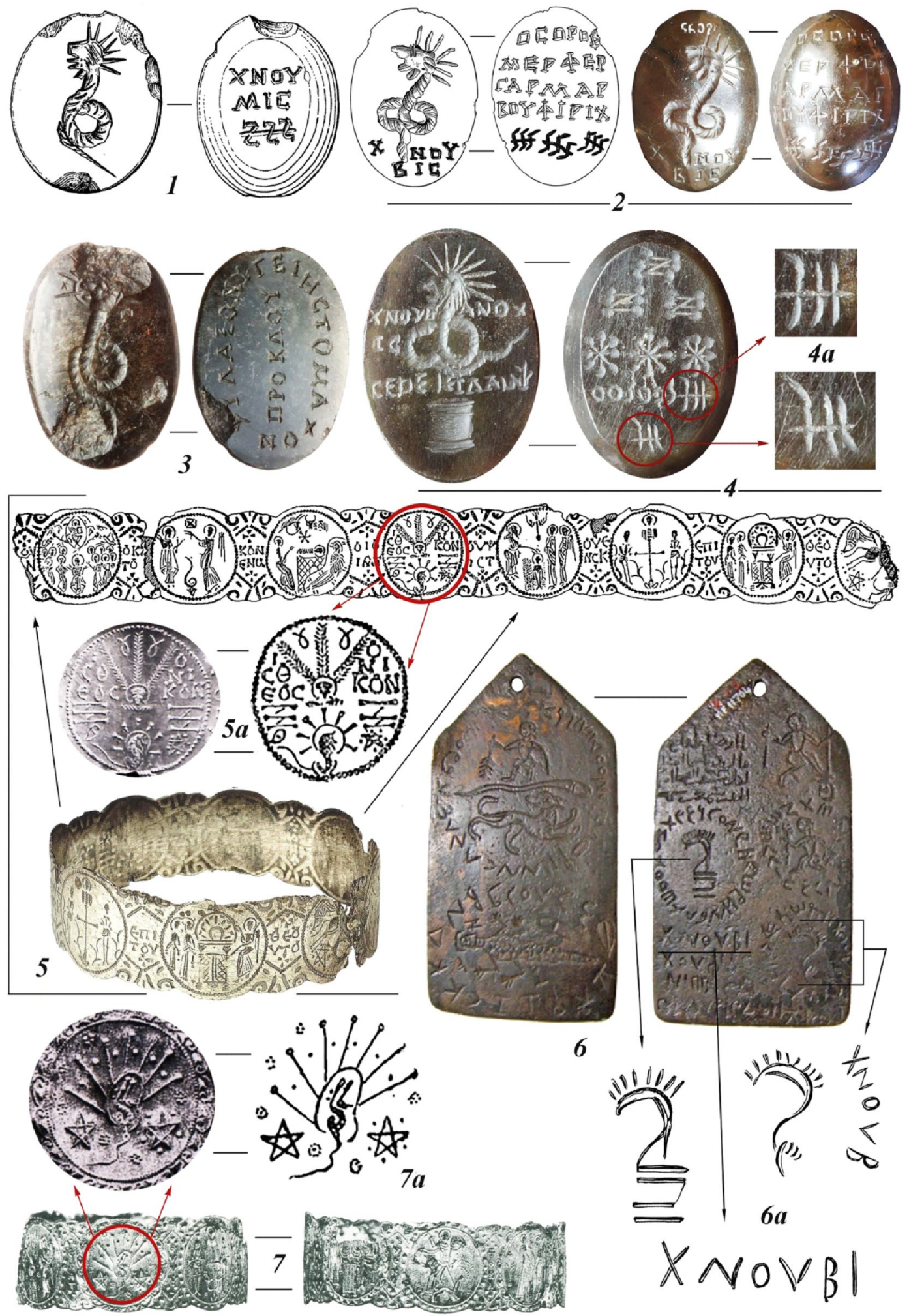

6

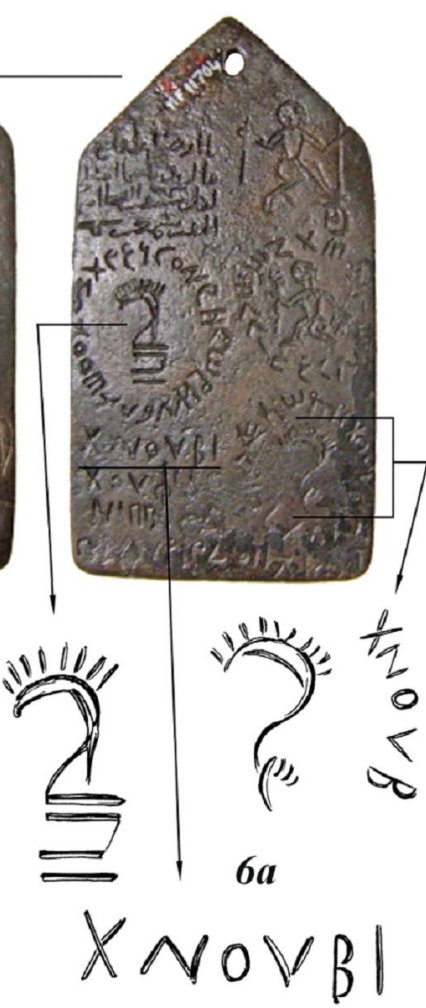

Рис. 5. Позднеантичные (1-4) и средневековые (5-7) амулеты с изображением Хнубиса:

1, 2, 4 - Британский Музей; 3 - Париж, Кабинет Медалей; 5, 7 - Египет; 6 - Париж, Лувр. 1-4 - [41, CBd-691; CBd-702; CBd-2943; CBd-698]; 5, 7 - [29, p. 247-248, fig. 1; 45, p. 35, 37, fig. 9b, 10d]; 6 - [15, p. 285, № AF11704]

Fig. 5. Late ancient (1-4) and medieval (5-7) amulets with the image of Khnubis: 1, 2, 4 - The British Museum; 3 - Paris, Cabinet des Médailles; 5, 7 - Egypt; 6 - Paris, the Louvre 


\section{СПИСОК ЛИТЕРАТУРЫ}

1. Агафий. О царствовании Юстиниана / пер., ст. и примеч. М. В. Левченко. - М. ; Л. : Изд-во Академии наук СССР, 1953. - 222 с.

2. Айбабин, А. И. Крымские готы страны Дори (середина III - VII в.) / А. И. Айбабин, Э. А. Хайрединова. - Симферополь : Антиква, 2017. - 368 с.

3. Айбабин, А. И. Топоним Климаты в средневековом Крыму / А. И. Айбабин // Вестник Волгоградского государственного университета. Серия 4, История. Регионоведение. Международные отношения. - 2019. - Т. 24, № 6. - С. 6-17. DOI: https://doi.org/10.15688/jvolsu4.2019.6.1.

4. Барабанов, Н. Д. К истории византийских народных верований. Истера / Н. Д. Барабанов // Античная древность и средние века. 2003. - Вып. 34. - С. 322-347.

5. Греческие молитвы, заклинания и заговоры из Большой Каракубы / вступ. ст., пер., коммент. и подгот. текста Е. Чернухина. - Донецк : НордПресс, 2005. - 167 c.

6. Латышев, В. В. Греческие и латинские надписи, найденные в Южной России в 1895-1898 годах / В. В. Латышев // Материалы по археологии России. - 1899. - № 23. - 76 с.

7. Неверов, О. Я. Гностические геммы, перстни и амулеты Юга СССР / О. Я. Неверов // Вестник древней истории. - 1979. - № 1. - С. 95-104.

8. Поляковская, М. А. Византия : Быт и нравы / М. А. Поляковская, А. А. Чекалова. - Свердловск : Изд-во Уральского университета, 1989. $308 \mathrm{c}$.

9. Хайрединова, Э. А. Медальоны с изображением святого всадника из могильника у с. Лучистое / Э. А. Хайрединова // Материалы по археологии, истории и этнографии Таврии. - 2014. Вып. ХІХ. - С. 147-210.

10. Хайрединова, Э. А. Перстень-амулет первой четверти VII в. из Юго-Западного Крыма / Э. А. Хайрединова // Античная древность и средние века. 2014. - Вып. 42. - С. 69-89.

11. Хайрединова, Э. А. Византийские перстни с надписью «Ф $\Omega \mathrm{C} \Omega \mathrm{Z} \Omega$ » из погребений крымских готов / Э. А. Хайрединова // Вестник Волгоградского государственного университета. Серия 4, История. Регионоведение. Международные отношения. - 2018. - Т. 23, № 5. - C. 88-104. - DOI: https:// doi.org/10.15688/jvolsu4.2018.5.8.

12. Хайрединова, Э. А. Перстни с изображением архангела Михаила конца VI - VII в. из Крыма / Э. А. Хайрединова // Вестник Волгоградского государственного университета. Серия 4 , История. Регионоведение. Международные отношения. 2019. - T. 24, № 6. - C. 32-46. - DOI: https://doi.org/ 10.15688/jvolsu4.2019.6.3.
13. Age of Spirituality : Late Antique and Early Christian Art, Third to Seventh Century / ed. K. Weitzmann. - New York: The Metropolitan Museum of Art, 1979. - $736 \mathrm{p}$.

14. Barb, A.-A. Bois du sang, Tantale/ A.-A. Barb // Syria. - 1952. - T. 29, Fasc. 3-4. - P. 271-284.

15. Bénazeth, D. L'art du métal au début de l'ère chrétienne / D. Bénazeth. - Paris : Eds. de la Réunion des musées nationaux, 1992. -303 p.

16. Bonner, C. Studies in Magical Amulets chiefly Graeco-Egyptian / C. Bonner. - Ann Arbor : The University of Michigan Press, 1950. - 335 p. (University of Michigan Studies. Humanistic Series ; Vol. XLIX).

17. Chambouillet, M. Catalogue général et raisonné des camées et pierres gravées de la bibliothèque impériale / $\mathrm{M}$. Chambouillet. - Paris : J. Claye, Imprimeur Librairie, 1858. -668 p.

18. Dasen, V. Le serpent léontocéphale Chnoubis et la magie de l'époque romaine impériale / V. Dasen, A. M. Nagy // Antropozoologoca. - 2012. - Vol. 47.1. P. 291-314.

19. Die Kunst der frühen Christen in Syrien. Zeichen, Bilder und Symbole vom 4. bis 7. Jahrhundert / Hrsg. M. Fansa, B. Bollmann. - Mainz : Verl. Philipp von Zabern, 2008. - $220 \mathrm{~S}$.

20. Die Welt von Byzanz. Europas Östliches Erbe / Hrsg. L. Wamser. - München : Theiss, 2004. - 475 S.

21. Faraone, Ch. A. Does Tantalus Drink the Blood, or Not? : An Enigmatic Series of Inscribed Hematite Gemstones / Ch. A. Faraone// Antike Mythen: Medien, Transformationen und Konstruktionen / Hrsg. U. Deli, C. Walde. - Berlin : De Gruyter, 2009. - P. 248-273.

22. Faraone, Ch. A. Text, Image and Medium: The evolution of graeco-roman magical gemstones / Ch. A. Faraone // «Gems of Heaven». Recent Research on Engraved Gemstones in Late Antiquity, c. AD 200-600 / eds. Ch. Entwistle, N. Adams. London : The British Museum, 2012. - P. 50-61.(British Museum Research Publication ; No. 177).

23. Faraone, Ch. A. A Copper Plaque in the Louvre (inv. AD 003732): Composite Amulet or Pattern-Book for Making Individual Body-Amulets? / Ch. A. Faraone // Kernos. - 2017. - Vol. 30. - P. 187-220.

24. Faskolou, V. The Magic of the Written Word: the evidence of inscriptions on Byzantine magical amulets / V. Faskolou // Deltion of the Christian Archaeological Society. - 2014. - Vol. 35. - P. 329-348.

25. Grabar, A. Un médaillon en or provenant de Mersine en Cilicie / A. Grabar // Dumbarton Oaks Papers. - 1951. - Vol. 6. - P. 27-49.

26. Hernández, R. M. More than a Logos. The I $\omega \varepsilon \rho \beta \eta \theta$ Logos in Context / R. M. Hernández // Litterae Magicae. Studies in Honour of Roger S.O. Tomlin / ed. C. S. Natalias. - Zaragoza : Libros Portico, 2019. P. $187-210$. 
27. Lancellotti, M. G. Médecine et religion dans les gemmes magiques / M. G. Lancellotti // Revue de l'histoire des religions. - 2001. - No. 4 (218). - P. 427-456.

28. Marcellus Empiricus. Marcelli de Medicamentis Liber / ed. Georgius Helmreich. Lipsiae : Aedibus B.G. Teubneri, 1889. -414 p.

29. Maspero, J. Bracelets - amulettes d'époque byzantine / J. Maspero // Annales du service des antiquités de l’Égypte. - 1908. - № 9. - P. 246-258.

30. Mastrocinque A. The Colours of Magical Gems / A. Mastrocinque // «Gems of Heaven». Recent Research on Engraved Gemstones in Late Antiquity, c. AD 200-600 / eds. Ch. Entwistle, N. Adams. London : The British Museum, 2012. - P. 62-68. (British Museum Research Publication; No. 177).

31. Mouterde, R. Le glaive de Dardanos, objets et inscriptions magiques de Syrie / R. Mouterde // Mélanges de l'université Saint-Joseph Beyrouth. 1930. - Vol. XV, fasc. 3. - P. 54-136.

32. Nemeti, S. Magical practices in Dacia and Moesia Inferior / S. Nemeti // Jupiter on your side. Gold and humans in Antiquity in the Lower Danube area / ed. C.-G. Alexandrescu. - Bucharest : Masterprint Super Offset, 2013. - P. 143-156.

33. Perdrizet, P. YГIA Z $\Omega H$ XАРA / P. Perdrizet // Revue des études grecques. - 1914. - T. 27, Fasc. 123-124. - P. 266-280.

34. Russell, J. The Archaeological Context of Magic in the Early Byzantine Period / J. Russell // Byzantine Magic / ed. H. Maguire. - Washington : Dumbarton Oaks, 1995. - P. 35-50.

35. Schlumberger, G. Amulettes Byzantins anciens destinées à combattre les maléfices et les maladies / G. Schlumberger // Revue des études grecques. 1892. - T. 5, Fasc. 17. - P. 73-93.

36. Seyrig, H. Individiae medici / H. Seyrig // Berytus Archaeological Studies. - 1934. - Vol. I. - P. 1-22.

37. Spier, J. Medieval Byzantine Magical Amulets and Their Tradition / J. Spier // Journal of the Warburg and Courtauld Institutes. - 1993. - Vol. 56. - P. 25-62.

38. Spier, J. Late Antique and Early Christian Gems / J. Spier. - Wiesbaden : Reichert Verl., 2007. - 221 p.

39. Spier, J. An Antique magical book used for making sixth-century Byzantine amulets? / J. Spier // Les saviors magiques et leur transmission de l'Antiquité à la Renaissance/ eds. V. Dasen, J.-M. Spieser. - Florence : Sismel-Ed. del Galuzio, 2014. - P. 43-66.

40. Sylloge Gemmarum Gnosticarum I / ed. A. Mastrocinque. - Roma : Libreria dello stato, 2003.478 p. - (Bollettino di Numismatica Monografia ; No. 8.2.I).

41. The Campbell Bonner Magical Gems Database. - URL: http://classics.mfab.hu/talismans/ (accessed 28 June 2020). - Title from screen.

42. The Greek Magical Papyri in Translation including the Demotic Spells / ed. H. D. Betz. -
Chicago ; London : The University of Chicago Press, 1986. $-397 \mathrm{p}$.

43. The Oxford Dictionary of Byzantium. Vol. 2 / Ed. A. Kazhdan. - New York ; Oxford : Oxford University Press, 1991. - P. XXXI, 729-1473.

44. Vikan, G. Art, medicine, and magic in Early Byzantium / G. Vikan // Dumbarton Oaks Papers. 1984. - Vol. 38. - P. 65-86.

45. Vikan, G. Two Byzantine Amuletic Armbands and the Group to Which They Belong / G. Vikan // The Journal of the Walters Art Gallery. - 1991/92. No. 49/50. - P. 33-51.

46. Walter, Ch. The Warrior Saints in Byzantine Art and Tradition / Ch. Walter. - Cornwall : Routledge, 2003. $-384 \mathrm{p}$.

47. Yashaeva, T. The Legacy of Byzantine Cherson / T. Yashaeva [et al.]. - Sevastopol ; Austin : Teleskop, 2011.- 708 p.

\section{REFERENCES}

1. Levchenko M.V., ed. Agafiy. O tsarstvovanii Yustiniana [About the Reign of Justinian]. Moscow; Leningrad, Academia Nauk SSSR Publ., 1953. 222 p.

2. Aibabin A.I., Khairedinova E.A. Krymskie goty strany Dori (seredina III - VII v.) [Crimean Goths in the Region of Dory (Mid-Third to Seventh Century)]. Simferopol, Antikva Publ., 2017. 368 p.

3. Aibabin A.I. Toponym Klimata in the Medieval Crimea. Vestnik Volgogradskogo gosudarstvennogo universiteta. Seriya 4. Istoriya. Regionovedenie. Mezhdunarodnye otnosheniya [Science Journal of Volgograd State University. History. Area Studies. International Relations], 2019, vol. 24, no. 6, pp. 6-17. DOI: https://doi.org/10.15688/jvolsu4.2019.6.1.

4. Barabanov N.D. K istorii vizantiyskikh narodnykh verovanii. Istera [To the History of Byzatine Popular Beliefs]. Antichnaya drevnost $i$ srednie veka [Antiquity and the Middle Ages], 2003, vol. 34, pp. 322-347.

5. Chernukhin E., ed. Grecheskie molitvy, zaklinaniia i zagovory iz Bolshoy Karakuby [Greek Prayers, Spells and Incantations from Bol'shaia Karakuba]. Donetsk, Nord-Press, 2005. 167 p.

6. Latyshev V.V. Grecheskie i latinskie nadpisi, naydennye v Yuzhnoi Rossii v 1895-1898 godakh [Greek and Latin Inscriptions Found in Southern Russia in 1895-1898]. Materialy po arkheologii Rossii [Materials on Archaeology of Russia], 1899, no. 23. 76 p.

7. Neverov O.Ia. Gnosticheskie gemmy, perstni $i$ amulety Yuga SSSR [Gnostic Gems and Amulets from Southern USSR]. Vestnik drevney istorii [Journal of Ancient History], 1979, no. 1, pp. 95-104.

8. Polyakovskaya M.A., Chekalova A.A. Vizantiya: byt i nravy [Byzantium: Life and Customs]. 
Sverdlovsk, Izd-vo Uralskogo universiteta Publ., 1989. $308 \mathrm{p}$.

9. Khairedinova E.A. Medalony s izobrazheniem svyatogo vsadnika iz mogilnika u s. Luchistoe [Medallions with the Image of Holy Rider from the Necropolis near the Village of Luchistoye]. Materialy po arkheologii, istorii i etnografii Tavrii [Materials in Archeology, History and Etnography of Tauria], 2014, vol. XIX, pp. 147-210.

10. Khairedinova E.A. Persten-amulet pervoy chetverti VII v. iz Yugo-Zapadnogo Kryma [The Amuletic Ring Dating Back to the First Quarter of the $7^{\text {th }}$ Century from the South-Western Crimea]. Antichnaia drevnost $i$ srednie veka [Antiquity and the Middle Ages], 2014, vol. 42, pp. 69-89.

11. Khairedinova E.A. Byzantine Finger Rings with the Inscription $\Phi \Omega P Z \Omega H$ from Burials of the Crimean Goths. Vestnik Volgogradskogo gosudarstvennogo universiteta. Seriya 4. Istoriya. Regionovedenie. Mezhdunarodnye otnosheniya [Science Journal of Volgograd State University. History. Area Studies. International Relations], 2018, vol. 23, no. 5, pp. 88-104. DOI: https://doi.org/10.15688/ jvolsu4.2018.5.8.

12. Khairedinova E.A. Finger Rings with the Image of Archangel Michael of the Late $6^{\text {th }}-7^{\text {th }}$ Centuries from Crimea. Vestnik Volgogradskogo gosudarstvennogo universiteta. Seriya 4. Istoriya. Regionovedenie. Mezhdunarodnye otnosheniya [Science Journal of Volgograd State University. History. Area Studies. International Relations], 2019, vol. 24, no. 6, pp. 32-46. DOI: https://doi.org/10.15688/jvolsu4.2019.6.3.

13. Weitzmann K., ed. Age of Spirituality: Late Antique and Early Christian Art, Third to Seventh Century. New York, The Metropolitan Museum of Art, $1979.736 \mathrm{p}$.

14. Barb A.-A. Bois du sang, Tantale. Syria, 1952, vol. 29, fasc. 3-4, pp. 271-284.

15. Bénazeth D. L'art du métal au début de l'ère chrétienne. Paris, Réunion des musées nationaux, 1992. $303 \mathrm{p}$.

16. Bonner C. Studies in Magical Amulets chiefly Graeco-Egyptian. Ann Arbor, University of Michigan Press, 1950. 334 p. (University of Michigan Studies. Humanistic Series; vol. XLIX).

17. Chambouillet M. Catalogue général et raisonné des camées et pierres gravées de la bibliothèque impériale. Paris, J. Claye, Imprimeur Librairie, 1858. 668 p.

18. Dasen V., Nagy A.M. Le serpent léontocéphale Chnoubis et la magie de l'époque romaine impériale. Antropozoologoca, 2012, vol. 47.1, pp. 291-314.

19. Fansa M., Bollmann B., eds. Die Kunst der frühen Christen in Syrien. Zeichen, Bilder und Symbole vom 4. bis 7. Jahrhundert. Mainz, Verlag Philipp von Zabern, 2008. 220 p.
20. Wamser L., ed. Die Welt von Byzanz. Europas Östliches Erbe. München, Theiss, 2004. 475 p.

21. Faraone Ch.A. Does Tantalus Drink the Blood, or Not?: An Enigmatic Series of Inscribed Hematite Gemstones. Deli U., Walde C., eds. Antike Mythen: Medien, Transformationen und Konstruktionen. Berlin, De Gruyter, 2009, pp. 248-273.

22. Faraone Ch.A. Text, Image and Medium: The Evolution of Graeco-Roman Magical Gemstones. Entwistle Ch., Adams N., eds. "Gems of Heaven». Recent Research on Engraved Gemstones in Late Antiquity, c. AD 200-600. British Museum Research Publication. London, The British Museum, 2012, pp. 50-61. (British Museum Research Publication; no. 177).

23. Faraone Ch.A. A Copper Plaque in the Louvre (inv. AD 003732): Composite Amulet or Pattern-Book for Making Individual Body-Amulets? Kernos, 2017, vol. 30, pp. 187-220.

24. Faskolou V. The Magic of the Written Word: the evidence of inscriptions on Byzantine magical amulets. Deltion of the Christian Archaeological Society, 2014, vol. 35, pp. 329-348.

25. Grabar A. Un médaillon en or provenant de Mersine en Cilicie. Dumbarton Oaks Papers, 1951, vol. 6, pp. 27-49.

26. Hernández R.M. More than a Logos. The Iōerbēth Logos in Context. Natalias C.S., ed. Litterae Magicae. Studies in Honour of Roger S.O. Tomlin. Zaragoza, Libros Portico, 2019, pp. 187-210.

27. Lancellotti M.G. Médecine et religion dans les gemmes magiques. Revue de l'histoire des religions, 2001, no. 4 (218), pp. 427-456.

28. Georgius Helmreich, ed. Marcellus Empiricus. Marcelli de Medicamentis Liber. Lipsiae, Aedibus B.G. Teubneri, 1889. 414 p.

29. Maspero J. Bracelets - amulettes d'époque byzantine. Annuales du service des antiquités de l'Égypte, 1908, no. 9, pp. 246-258.

30. Mastrocinque A. The Colours of Magical Gems. Entwistle Ch., Adams N., eds. «Gems of Heaven». Recent Research on Engraved Gemstones in Late Antiquity, c. AD 200-600. London, The British Museum, 2012, pp. 62-68. (British Museum Research Publication; no. 177).

31. Mouterde R. Le glaive de Dardanos, objets et inscriptions magiques de Syrie. Mélanges de l'université Saint-Joseph Beyrouth, 1930, vol. XV, fasc. 3, pp. 54-136.

32. Nemeti, S. Magical practices in Dacia and Moesia Inferior. Alexandrescu C.-G., ed. Jupiteron your side. Gold and humans in Antiquity in the Lower Danube area. Bucharest, Masterprint Super Offset, 2013, pp. 143-156.

33. Perdrizet P. YGIA ZŌĒ CHARA. Revue des études grecques, 1914, vol. 27, fasc. 123-124, pp. 266-280.

34. Russell J. The Archaeological Context of Magic in the Early Byzantine Period. Maguire H., ed. 
Byzantine Magic. Washington, Dumbarton Oaks, 1995, pp. 35-50.

35. Schlumberger G. Amulettes Byzantins anciens destinées à combattre les maléfices et les maladies. Revue des études grecques, 1892, vol. 5, fasc. 17, pp. 73-93.

36. Seyrig H. Individiae medici. Berytus Archaeological Studies, 1934, vol. I, pp. 1-22.

37. Spier J. Medieval Byzantine Magical Amulets and Their Tradition. Journal of the Warburg and Courtauld Institutes, 1993, vol. 56, pp. 25-62.

38. Spier J. Late Antique and Early Christian Gems. Wiesbaden, Reichert Verl., 2007. 221 p.

39. Spier J. An Antique magical book used for making sixth-century Byzantine amulets? Dasen V., Spieser J.-M., eds. Les saviors magiques et leur transmission de l'Antiquité à la Renaissance. Florence, Sismel - Ed. del Galuzio, 2014, pp. 43-66.

40. Mastrocinque A., ed. Sylloge Gemmarum Gnosticarum I. Roma, Libreria dello stato, 2003. 478 p.
41. The Campbell Bonner Magical Gems Database. URL: http:/classics.mfab.hu/talismans/ (accessed 28 June 2020).

42. Betz H.D., ed. The Greek Magical Papyri in Translation including the Demotic Spells. Chicago; London, The University of Chicago Press, 1986. 397 p.

43. Kazhdan A., ed. The Oxford Dictionary of Byzantium. Vol. 2. New York, Oxford University Press, 1991, pp. XXXI, 729-1473.

44. Vikan G. Art, medicine, and magic in Early Byzantium. Dumbarton Oaks Papers, 1984, vol. 38, pp. $65-86$.

45. Vikan G. Two Byzantine Amuletic Armbands and the Group to which They Belong. The Journal of the Walters Art Gallery, 1991/92, no. 49/50, pp. 33-51.

46. Walter Ch. The Warrior Saints in Byzantine Art and Tradition. Cornwall, Routledge, 2003. 384 p.

47. Yashaeva T., Denisova E., Ginkut N., Zalesskaya V., Zhuravlev D. The Legacy of Byzantine Cherson. Sevastopol, Austin, Teleskop, 2011. 708 p.

\section{Information About the Author}

Elzara A. Khairedinova, Candidate of Sciences (History), Head of the Department of Mediaeval Archaeology, Institute of Archaeology of Crimea of the Russian Academy of Sciences, Prosp. Akademika V.I. Vernadskogo, 2, 295007 Simferopol, Russian Federation, khairedinovaz@rambler.ru, https://orcid.org/0000-0002-1362-757X

\section{Информация об авторе}

Эльзара Айдеровна Хайрединова, кандидат исторических наук, заведующая отделом средневековой археологии, Институт археологии Крыма РАН, просп. академика В.И. Вернадского, 2, 295007 г. Симферополь, Российская Федерация, khairedinovaz@rambler.ru, https://orcid.org/0000-0002-1362-757X 